\title{
Human Fear of COVID-19: Social Protection Over Self Interest
}

\author{
Noura Abdel Maksoud Eissa ${ }^{1}$ \\ ${ }^{1}$ Economics, Faculty of Economics and Political Science, Future University in Egypt FUE, Egypt \\ Correspondence: Assistant Professor, Economics, Faculty of Economics and Political Science, Future University in \\ Egypt FUE, Egypt.
}

Received: July 6, 2020

doi:10.5430/rwe.v12n2p240

Accepted: August 11, 2020

Online Published: February 20, 2021

URL: https://doi.org/10.5430/rwe.v12n2p240

\begin{abstract}
The aim of this article is to communicate a view of how fear as a human emotion transforms individual behavior, shapes state interests and changes country perceptions of self-interest, somehow colliding with their interests in the context of international relations and globalization. The article is a thought piece, supported by various theories embedded in the discussion of the COVID-19 pandemic events. Findings convey that overcoming fear and offering empathy in means of social protection, is the new self-interest that most countries followed in a domino pattern. The paper also provides meaningful insights for facing future crises within the very fast global pandemic events and within the context of available information. It has been written during the time of the COVID-19 pandemic and the current lock down with academic originality on such a fresh topic. It is of value added because it brings in human emotions such as fear of uncertainty in pandemics and uses a macro-interdisciplinary approach to understand how they shape the behavior, perception, and actions of countries.
\end{abstract}

Keywords: coronavirus, uncertainty, anxiety, economic growth, crisis

\section{Introduction}

In times of crises, when fear becomes the dominant trait, individual state power somehow becomes unleashed with either its strengths or weaknesses. A pandemic brings about a new set of human beliefs and behaviors where people and their countries are socially transformed into credulous individuals, unwilling to experience anything that is unfamiliar to them (El Erian, April 2020). It is defined as a mass scale omnipresence of life-saving threats, uncertainty and fear because of the spread of sickness and disease. French philosopher Michael Foucault once described the $18^{\text {th }}$ century plague as a spatial partitioner and a population sub-divider where "dangerous communications, disorderly communities and forbidden contacts can no longer appear" (Sarasin, 2020).

Months before the outburst of the novel COVID-19, political scientist and Professor of political science and international relations, Abdul-Monem Al-Mashat predicted the possibility of a global economic recession, with a complete paralysis in world production systems, allocation of resources, and trade (November 2019). As predicted, the global economic recession came shortly after the 11th of March 2020, when COVID-19 was declared a pandemic by the Director General of the World Health Organization WHO; world economies experienced domino patterns of lockdowns in human and economic mobility in order to "flatten the curve" and halt the disease from spreading. The pandemic has legitimized individual country self-interests of national restrictions over global interests in terms of trade and foreign direct investment FDI flows (Le Grain 2020). Long-term discussions are put on the table on how countries should outweigh the balance between openness and protectionism, interdependence and self-reliance. Economist Stigliz (April 2020) declared the COVID-19 pandemic as a global problem that demands a global solution (April 2020); Al-Mashat (April 2020) emphasized that an "inclusive" structure in the world structure is required to offer social protection and human solidarity.

The objective of this paper is to convey how individual states should place human emotions of fear as a priority with social protection as the national self-interest competing again international relations' self-interests. This paper is a thought piece, supported by embedded political, anthropological, and economic theories to explain human rational within text, and current articles documented in reliable world magazines. In times of crises, countries follow the behavioral steps of each other, through a domino pattern. Insights are interdisciplinary and convey solutions that should be based on social protection and human solidarity, with public policy being a priority over private policy. 


\section{Research Methods}

The author has set out a platform enforcing potential on how nation-states could find solutions to crisis management by linking between the dynamism of international relations, the dilemma of human fear and social protection and the colliding competition over self- interest. This is done through a multidisciplinary analysis of economic, political, and anthropological theories. Recommendations are consequently set forth.

\section{Literature Review}

The literature review is sequenced to explain the term fear within the nature of international relations, fear in context of the COVID-19 virus, followed by fear within the global context and the domino effect of countries following the behavior of one another.

\subsection{Fear as Defined in International Relations}

According to various literature, in world politics, the notion of fear, has different dimensions, all related to human emotions. Primarily, fear is derived from uncertainty, a "symptom of pervasive conflict and political unhappiness" (Robin 2004). Uncertainty is an induction of fear and an attribute to something that may happen (Bleiker and Hutchinson 2008). Fear is simply an inevitable emotion that influences world politics (Linklater 2014) forcing states to compete against one another and/or to cease efforts of cooperation and trust. In the COVID-19 case, according to Mohamed El Erian, uncertainty is related to "the duration and severity of the economic lockdown, the nature of the eventual restart and the post-crisis landscape, along with the medical judgment to flatten the infection curve" (April 13, 2020). Second, fear is embedded in the neorealists (Note 1), theoretical framework to operate within the nature of the human being, with cognitive and emotional practices as determinants of how the state acts and as a reaction to power-maximizers and self-helping (Brent 2011). Third, fear built within political actors is manifested in identifying portraits of enemies, justifying political agendas.

Fear of uncertainty shapes world politics in its power to halt cooperation among nation states. For state cooperation to become effective or to even exist, overcoming fear must be the number one step. States' behaviors are a derivative of fear of uncertainty and a determinant of whether state cooperate among themselves or through international organizations as preferred by institutionalists (Tang 2008); international organizations cannot eliminate fear of uncertainty but they pave the road for the future, make the international system seem predictable and less hostile (Axelrod and Keohan 1985). An individual state's perception and process of interpretation of the behavior of other states is another form of fear of uncertainty. For instance, through a content analysis of former United States Secretary of State, John Foster Dulles' speeches, developed, bad thinking of the Soviet Union, as deceptive and evil, resulting into a false sense of security (Larson 1997).

\subsection{Fear in the Globalization Context}

The same dilemma stands in the fear of uncertainty in countries missing out on the waves of globalization becoming outcasts in the global world. According to Stiglitz, global action is a matter of self-interest (2020). Globalization is a process that transforms separate entities into a collective social relations network (Sideri 2000). Globalization is "a growth of economic activity across national and regional borders, which reflects itself in increased movement of goods, services, property rights within trade flows and in movement of people within migration flows" (Klein 2000). Globalization as such is a flow process of the logic of market integration with an alliance of global governance oriented essentially toward the maximization of market efficiency in the interests of growth and development. Individual state fears of scarcity in resources versus growing population demands is consistent with the increased dependence on foreign resources through trade globalization and international relations. are consistent with the increased dependence on foreign resources (Hellenthal et al., 2014).

In steady state, no crisis circumstances, the same fear of uncertainty in being labeled as a strong state versus a weak state is evident as an impact of globalization. Strong states are those which shape the rules and institutions enforcing the existence of a global economy and in control to some degree of the nature and speed of their integration into the world economy (Acemoglu 2005). In common and with equal ferocity, strong states guard their independence in economic policy, foreign policy, human rights and security issues. Weak states by contrast suffer from a lack of choice in their international economic relations with minimal influence in the creation and enforcement of rules in the system or over their own integration into the world economy. Both old and new globalization trends position strong nations in a prioritized leadership of dictating trade offers to the weaker nations. Old globalization or interchangeably internationalization is "trade led by advanced nations in the form of Foreign Direct Investment FDI under Multinational Corporations MNCs to emerging countries offering both resources and markets" (Peters 2010). New globalization is parallelized with global capitalism. Globalization calls for an open economy environment 
where emerging nations are faced with waves of economic and political pressures urgently calling for adjustments in both their regional and international policies. Despite such a fact, as stated earlier the existence of international institutions does not guarantee cooperation among nation states specifically with the existence of fear, be it the fear of uncertainty due to a pandemic, or the lack of resources.

In times of crises common with global pandemics, military conflicts and political instability, countries whether advanced or emerging resort back to the nature of human beings and emotional fear of uncertainty, to trade protectionism and self-sufficient production; this is driven by self-interest maximizing profit goals and in return negatively impacting global trade by increasing its costs. Notwithstanding the fact that globalization has for so long been perceived as an intriguing path to global prosperity, the original reason for the creation of most unions was a result of warfare rather than peaceful negotiations (Hou and Hou, 2002). Nation states have promoted the evolution of political institutions beneficially raising the risk of warfare due to economics and military imbalances, countries with different political systems and variations in military strength (Cao, 2015). In other words, global stability is dictated with growing fears of change towards more militaristic policies, with an urging necessity to find ways to ease those fears and find solutions to avoid military action.

\subsection{Domino Effect: Nation States Copying Each Other in Behavior}

The domino effect is more of a classical chain reaction, where toppling the first domino in a row, will bring down the entire row. The domino theory was adopted by the United States during the US-Vietnam war, as a reason for entering the war against "communism", arguing that if one new Asian country entered into communism, a chain reaction would lead the rest of the Asian countries to follow such pattern, causing a fear of "communism" to the United States (O’Sullivan 1996).

In the pandemic era of COVID-19, two things are quite interesting to consider. First, the domino effect, or the classical chain reaction, has been quite clear in terms of post-fear reactions in individual world states, one country locks down, the other follows, one country imposes trade and border restrictions, the other one copies it, and so on. Second, karma, here has played an interesting role, now the same way back when US was legalizing its invasion to Vietnam using the domino theory, the roles have been switched, with China, Russia, and Asian countries catching up on the role of falling capitalism and the rise of socialism; this is just a note to consider but this is not the scope of the paper, and will require further research. In addition to that, the global world, in a domino pattern, have discovered the importance of allowing public governments to have the upper hand in the decision-making process against private institutions, in other words mixed economies are required with a public-private cooperation (public holding the upper hand).

\section{COVID-19-First Level of Fear Within Individuals}

With the COVID-19, the natural state of fear and panic by individuals is the first level "coming less from the risk of infection and more from the growing reality of its fall out" (Manderson \& Levine 2020). Social distancing according to medical anthropologists affects the social and economic life of individuals and creates feelings of anxiety, stress, and even depression (Briggs 2005). When faced with fear, individuals are hit by sudden changes in their normal behaviors, in line with the required precautionary actions such as washing their hands on a regular basis, using disinfectants, hand sanitizers, bumping elbows instead of normal greetings of hugging, kissing, and even shaking hands. More psychological pressures on individuals who are born to be social came as a result of the mediatization of the pandemic through the domino pattern of closing schools, universities, libraries, and museums, the cancellation of conferences, and eventually followed by whole country lockdowns. The current pandemic of COVID-19, as analyzed by anthropologists, has impacted how human practices and behaviors are implicated, and how a global humanitarian crisis, such as a community transmission of the disease can turn into a global pandemic. Anthropologist Nikiwe Solomon clarifies the urging need for counter-intuitive actions, for self-protection and for the protection of others (Manderson \& Levine 2020). Some individuals have even gone deeper in their analysis and started to question the sustainability of global capitalism.

In the past decades, medical anthropologists concluded that the fear of infection by pandemics directly feeds into social exclusion and discrimination; examples include HIV, SARS, H1N1 (Parker 2001). In the case of the COVID-19, individuals who have access to the basic human hygiene sources discriminate against individuals who are less fortunate or lacking sanitation, water shortages, soaps, sanitizers, etc. The fear of interaction between the two groups is a type of human racism and discrimination. This is also evident with individuals working in the informal sector and/or community health workers, slums areas, in South Africa, Kenya, and Nigeria, cities like Rio de Janeiro and Mexico City, and cramped refugee camps in east Africa, Turkey, Jordan, Bangladesh, and Pakistan. 
Discrimination because of fear and lack of equipment to halt such fears can lead to structural violence, with individuals becoming higher at risk of being infected (Quesada et al 2011).

\section{Second Level of Fear: Nation-State Fear as a Self Interest and International Relations}

\subsection{Scenario One: Fear of Insecurity: Lockdown Versus Economic Recession}

The fear of uncertainty of the spread of translated into social protection as a self-interest is pressured against the country's interests in avoiding an economic recession. This is evident in the variations in duration and in the degree of reluctance towards the lockdown as demonstrated by the domino pattern of most countries like China, the United States, and Italy in hopes of avoiding economic immobility in terms of resources and trade. Social protection, embedded in the neorealist theoretical framework within the emotional and cognitive nature of human beings, does not only come in the form of saving lives and preventing the spread of the COVID-19 but also from the fear of pressure from "domestic and international nonstate actors." Although the opportunity cost of increasing social protection is an economic recession, countries in a domino pattern have resorted to the first option, proving that the existence of fear hinders country cooperation and has shaped the nature of international relations. The Chinese government, as reported by the Guardian, knew of the COVID-19 ever since November 2019, but deliberately censored media reports and "cracked down on whistleblowers concerned about a new SARS-like virus emerging in Wuhan" until lockdown on January 23 (2020). In a similar domino pattern of behavior, the delay in the lockdown in Italy was triggered by a fear of insecurity of an upcoming economic recession outweighed by a fear of insecurity in protecting civilizations from the disease and in turn, becoming globally internalized; investment firm Goldman Sachs stated that the sectors most affected by the lockdown include tourism, travel, hospitality, and retail and account for about 23 percent of the Italian Gross Domestic Product.

\subsection{Scenario Two: Fear of Losing Global Reputation Versus Fear of Additional Responsibilities on National} Governments

Countries fear of losing their global reputation as advanced capitalist states prioritizing the health and social protection of their citizens is outweighed against the fear of levying additional pressures and responsibilities on individual national governments. On another wavelength, China has paved way in demonstrating that in crisis times, a harsh grip of dictatorship is needed to contain the viral spread. Resorting back to the topic, both the United Kingdom and the United States, following one another, were reluctant to declare a "state of exception", being slow in imposing lockdown measures, and being aware of their inadequate subsidized healthcare as in the UK or nonexistent as in the US. Declaring a state of exception is an unspoken fear of uncertainty, affecting the dimensional mobility of people, goods, and financial markets and putting additional responsibilities on the national governments. In the state of exception, as Agamben explains, the discipline of governmental power has been questioned with an imperative to protect humanity through quarantining and levying more pressure on the broken welfare system and health care structure versus stubbornness against the inclination to save the US financial market in the global world (2020). The federal government downsized the severity of the virus for several weeks to prepare itself to trumpet private-public partnerships, testing its public infrastructure, aiding banks with $\$ 1.5$ trillion in short-term loans to prevent a financial crisis. It finally surrendered to its fear of losing its global reputation as a social protector of its people and released social distancing guidelines and a lock down mid-March; the US situation is deeply integrated within the neoliberal (Note 2) state, that the government will fall dysfunctional without the functioning of the private sector specifically the giant multinational corporations.

\subsection{Scenario Three: Fear of Individual Social Protection Versus Bloc Integration}

The fear of uncertainty in losing the grip on individual social protection over bloc integration interests has become evident in the European Union. Immobile movements within EU countries violate the main essence of a regional bloc which should include free movements among member states. The reliability and cohesion of the European Union has been tested even before the COVID-19 pandemic with the effects of the 2008 financial crisis, increasing autocracy in the east, 2015 migration surges and now the COVID-19 pandemic. Although the European commission proposed a program to protect the EU countries of the negatives of the pandemic, individual state "fears" have stood reluctant against bloc interests of maintaining their global reputation and solidarity as a regional economic bloc. In significance, the EU's open door Schengen agreement has been locked down by travel restrictions between Germany and Austria, Belgium and France, France and Italy, and so on. This explains the outweigh of individual state interest of social protection through social distancing over the global well-being interest of the EU as an economic bloc.

Another form of fear faced by the EU during the COVID-19 pandemic has been the emotional dominance of strong states over resentful feelings of weaker states in the European Union. The European Commission program outlined a 
protection to jobs and workers affected by the COVID-19 to 100 billion Euros, and an aid scheme of 50 million Euros for Italy to provide medical equipment, as well as a stimulus package of 750 billion Euros to help keep the Eurozone as is (Morris and Birnbaum 2020). Examples include stronger EU countries like Germany and the Netherlands, being criticized of not aiding Italy of Spain during the COVID-19 pandemic effectively; as stated by Katya Adler, although Germany sent medical masks to Italy, and treated COVID-19 patients from France and Italy into its hospitals for treatment, it has also ironically rejected a plea by Italy, Spain, France and others to share out coronavirus-incurred debt in the form of corona bonds (Eurobonds) (2020). Instead, Germany validated its decision backing it up by the European Stability Mechanism, a bailout fund created post the 2008 crisis, with tough conditions insisted by Austria and the Netherlands. Italy's resentment and fear of collapse has been portrayed by complaints that it was not supported by the stronger states of the bloc, was being punishing for suffering economically from a pandemic virus; videos of EU flag-burning circulated on Italian and global social media networks went viral giving an image of the overriding individual state self-interests in protecting civilians over bloc interests or images.

The third type of fear in the EU has been the fear of false perceptions among member states. Racism acts as an emotional tensioner of whether country $\mathrm{x}$ is a plague bearer or not. Francois Heisbour of the International Institute for Strategic Studies stated, "It could create enormous resentment. You are an Italian and you are considered as a plague-bearer by Germans. This is where the real danger for Europe lies"( Morris, L. \& Birnbaum, M. 2020). Overcoming these three shapes of fear, through a better understanding of human solidary and collective action in a domino manner, would allow the recreation of a stronger EU within their neoliberal cooperative framework.

\section{Third Level Fear: The Use of Threats to Cover up for Crisis Management Weaknesses}

Globally stronger countries who are fearing being viewed as vulnerable whilst the pandemic cover their fears by threatening relatively weaker countries; such threats convey how fear can reshape global relationships, with an explanation of strong states guarding their global status. For instance, the United States as a strong state in shaping and enforcing the existence of the global economy has threatened Saudi Arabia with the imposition of sanctions tariffs if it did not solve the oversupply of oil in the market (Reuters 2020); the threat to Saudi Arabia is more of a cover-up of the United States fear to protect its own oil industry and its pandemic crisis. The United States also managed to threaten India with sanctions if it did not take action to ban the export of medication to cure COVID-19; India did partially lift a ban on its export but with ferocity of protecting its own individuals, setting its own set of rules against the United States; this depends on the Indian export stock available of hydroxychloroquine and paracetamol and meeting the domestic demand of its people (COVID-19: Govt tightens export ban norms for anti-malarial drug hydroxycloroquine (2020, April 5).

A different form of threat has been the domino pattern of countries hijacking face mask shipments, translated into a fear of shortages in protective equipment to fight the COVID-19 over irrational actions to secure such equipment. The hijacking of a consignment of masks dispatched from China to France, when suddenly on the plane at the Shanghai airport, US buyers bid an offer three times what the French were willing to pay (Amlot 2020). Furthermore, the fear of shortages in masks has led to a stockpiling of materials, and therefore limiting the export of protective medical equipment including France, and Russia ironically countries within one economic bloc, the EU). Belgian and Italian newspaper reports stated hinting on the hijacking of Turkish made masks destined for those countries, and had never been sent.

\section{Alternatives to COVID-19 Fear: Truth, Trust, and Love}

Countries that have proven their successful battle over the COVID-19 virus have overcome fear using truth, trust, and love. Angela Merkel, chancellor of Germany, conveyed the truth to her people from the early start claiming that around $70 \%$ of Germans would be infected; this basically jump-started Germany and its people right over the phases of denial, anger, and panic. With truth conveyed, the government became trustworthy and credible in its decision-making process of early testing and early tracking of the disease and thus delivering a robust health care system (Benhold 2000). According to John Hopkins University, the conduction of around 350,000 coronavirus tests a week, the pandemic was flexibly contained and slowed down. In fact, Germany copied (in a domino manner) the successful strategy of South Korea in tracking the COVID-19 cases. Germany's absorptive capacity that was already existent in health care systems and intensive units allowed acceptance of patients from Italy, Spain and France.

In Taiwan, Tsai Ing-wen, did not follow the same domino pattern of lockdowns, instead, with the first signs of new illness, her fast decisiveness allowed the introduction of 124 measures to block the spread, and even sending 10 million face masks to the US and Europe, reporting only six deaths (Cox 2020). Similarly, avoiding the lockdown approach, Norway's Prime Minister, Erna Solberg, innovatively introduced television to talk directly to her country's children, comforting them psychologically into why it is normal to have feelings of fear (Cox 2020). 
Innovative alternatives based on human solidarity and human understanding in a collective manner have brought about positive results in containing the spread of the COVID-19 pandemic. This is in comparison to the previously mentioned countries who have used threats, blames, hijacking and discrimination to protect their "global images" and their "political systems." Such countries have not only entered into a pandemic crisis with the fear of the unknown combined with an economic crisis, but have been hit hard by a political structural crisis.

\section{Concluding Insights}

With the dynamism of international relations, fear continues to overflow in world politics as a human emotion that is determined by uncertainty, influences a state's motives, and shapes the state's human level through individual perceptions. Fear, primarily stemming from individuals, demonstrates how a state self-interest collides with international relations among states and thus globalization. With pandemics such as the COVID-19, states have proven that the fear of losing individuals lives or interchangeably social protection is the new self- interest of most of the world states, done in a domino pattern, and outweighing self-interests that are linked to international relations in the global context. Thoughtful insights are written in a form of tarot-reading, analyzing the given events and information, offering promising but not necessarily perfect solutions to the global pandemic problem.

No. One: A macro-interdisciplinary, inclusive and collective, approach is best to use when analyzing situations that involve human emotions such as fear since it involves anthropology, sociology, economics, and political science. There is no right or wrong answer, it is mostly all about trial and error.

No. Two: To protect the individual in his/her state of fear, uncertainty, and anxiety, governments should step in and take the upper hand role than the private sector. This will increase the absorptive capacity of public entities and enhance social protective schemes and public services that would target the quality of human lives such as healthcare and education.

No. Three: with fear being a relative concept, governments should think out of the box in steady-times and more importantly in times of crisis, things can be done differently in a reversible manner as long as they make sense. For example, Spain, as a response to the COVID-19 pandemic, temporarily rushed to nationalize all the private hospitals and healthcare providers, an impossible step to either discuss or implement before the crisis. Policymakers could play the role of several decision makers in the country to understand the different perceptions and concerns for each group.

No. Four: In times of crises, when fear becomes dominant, countries usually copy one another in a domino effect, and this could work either as an advantage or a disadvantage in rebuilding the world through collective action, benefiting the individual, through welfare.

No Five: Building Global Awareness on Human Solidarity and in return creating systems of global solidarity is required to build quality individuals

To demonstrate acts of solidarity to overcome fear, all countries starting with the public sector on top of the private sector should first build awareness on the importance of different acts of solidarity, and then find alternatives to build such acts beyond crises. First, value-added services that would either enhance individual physical, educational, and even leisure skills are to become available for free on online platforms; this includes educational services, entertainment services such as theatre visits, museum visits, or yoga classes. Second, labor rights, specifically to those working in the informal sector and or receive hourly earnings, should gain a priority and should become part of the financial inclusion scheme. Third, public services specifically the health care sector should be placed as a top priority.

\section{Future Research}

Future research involves the dynamic and changeable role of social protection in the context of fear. A deeper insight would highlight the role of public governments in crisis management decision making processes, conducted in multilateral terms, in public-private collaborative terms, and finally within a global context. This could be done in a comparative country case study manner: within the public government framework of relative policies, relative timings in decision making, and in relative social protection methods.

\section{References}

Acemoglu, D. (2005). Politics and economics in weak and strong states. National Bureau of Economic Research Working Paper 11275.

Adler, K. (2020, April 3). Coronavirus outbreak eats into EU unity. The Guardian. Retrieved from https://www.theguardian.com/world/2020/apr/02/global-battle-coronavirus-equipment-masks-tests 
Agamben, G. (2020, February 26). The state of exception provoked by an unmotivated emergency. Positions Politics. Retrieved

from http://positionswebsite.org/giorgio-agamben-the-state-of-exception-provoked-by-an-unmotivated-emergency/

Al-Mashat, A. M. (2020, April 6). The new international order is South-Asian. Al Ahram Al Iktisadi.

Al-Mashat, A. M. (2020, November). The international order: Global imbalance. Al Ahram Al Iktisadi.

Amlôt, M. (2020, April 5). Coronavirus: Countries begin hijacking medical goods over supply shortage fears. Al Arabiya.

Retrieved

from https://english.alarabiya.net/en/features/2020/04/05/Coronavirus-Countries-begin-hijacking-medical-goods-over -supply-shortage-fears.html

Axelrod, R., \& Keohane, R. (1985). Achieving cooperation under anarchy: Strategies and institutions. World E-International Relations. How Fear Shapes World Politics Written by Natalie Alfred Politics, 38(1), 226-254.

Benhold, K. (2020, April 6). A German exception? Why the country's coronavirus death rate is low. The New York Times.

Retrieved

from https://www.nytimes.com/2020/04/04/world/europe/germany-coronavirus-death-rate.html

Bleiker, R., \& Hutchinson, E. (2008). Fear no more: emotions and world politics. Review of International Studies, 34(S1), 115-135.

Brent, S. (2011). Theorizing states' emotions. International Studies Review, 13(3), $452-476$.

Briggs, C. L. (2005). Communicability, racial discourse, and disease. Annual Review of Anthropology, 34, 269-291. https://doi.org/10.1146/annurev.anthro.34.081804.120618

Cao, S. (2015). A win-win path for institutional change. Time \& Society, 25. https://doi.org/10.1177/0961463X15577275

COVID-19: Govt tightens export ban norms for anti-malarial drug hydroxycloroquine. (2020, April 5). The Economic Times.

Retrieved

from https://economictimes.indiatimes.com/industry/healthcare/biotech/pharmaceuticals/COVID-19-govt-tightens-ex port-ban-norms-for-anti-malarial-drug-hydroxycloroquine/articleshow/74992670.cms?from=mdr

Cox, A. W. (2020, April 13). What do countries with the best coronavirus responses have in common? Women leaders. Forbes. Retrieved from https://www.forbes.com/sites/avivahwittenbergcox/2020/04/13/what-do-countries-with-the-best-coronavirus-re ponses-have-in-common-women-leaders/\#30bfa4583dec

El Erian, M. A. (2020, April 13). More shock and awe stimulus may be needed. Bloomberg. Retrieved from https://www.bloomberg.com/opinion/articles/2020-04-12/coronavirus-more-shock-and-awe-stimulus-may-be-n eeded

El Erian, M. A. (2020, April 8). COVID-19 and the rise of the pandemic economy. Channel New Asia. Retrieved from

https://www.channelnewsasia.com/news/commentary/COVID-19-coronavirus-fiscal-stimulus-package-bank-rec ession-jobs-12605646

Hellenthal, G., Busby, G. B. J., Band, G., et al.. (2014). A genetic atlas of human admixture history. Science, 343.

Hou, C. C., \& Hou, J. W. (2002). Evolution of economic institutions and China's economic reform. Social Science Journal, 39.

Jack, S., Levy, J. S., \& Barnett, M. N. (1992). Alliance formation, domestic political economy, and third world security. Jerusalem Journal of International Relations, 14(4).

Klein, C. (2000). Joining the global rules-based economy: challenges and opportunities for the GCC. Remarks, Twentieth in the Capitol Hill Conference Series on US Middle East Policy, Middle East Policy Council, Washington, DC.

Larson, D. W. (1997). Trust and missed opportunities in International Relations. Political Psychology, 18(3), 701-734.

Le Grain, P. (2020, March 12). The coronavirus is killing globalization as we know it. Foreign Policy. Retrieved from https://foreignpolicy.com/2020/03/12/coronavirus-killing-globalization-nationalism-protectionism-trump/

Linklater, A. (2014). Anger and World Politics: How collective emotions shift over time. International Theory, 6(3), 574-578. 
Lister, T., \& Shukla, S. (2020, April 3). Coronavirus sparks a war for masks' as accusations fly. Retrieved from https://edition.cnn.com/2020/04/03/europe/coronavirus-masks-war-intl/index.html

Manderson, L., \& Levine, S. (2020). COVID-19, risk, fear, and fallout, medical anthropology. https://doi.org/10.1080/01459740.2020.1746301

Morris, L., \& Birnbaum, M. (2020, April 3). European leaders warn coronavirus could lead to the breakup of their union. The Washington Post. Retrieved from https://www.washingtonpost.com/world/europe/coronavirus-europe-unity/2020/04/02/4c9ed8c0-743e-11ea-ad9 b-254ec99993bc_story.html

O'Sullivan, P. (1996). Dominoes or dice: geography and the diffusion of political violence. Journal of Conflict Studies, 16(2).

Parker, R. (2001). Sexuality, culture, and power in HIV/AIDS research. Annual Review of Anthropology, 30, 163-179. https://doi.org/10.1146/annurev.anthro.30.1.163

Peters, M. (2010, June). The changing pattern in international trade and capital flows of the gulf cooperation council countries in comparison with other oil-exporting countries. European Economic Papers.

Quesada, J., Hart, L. K., \& Bourgois, P. (2011). Structural vulnerability and health: Latino migrant laborers in the United States. Medical Anthropology, 30(4), 339-362. https://doi.org/10.1080/01459740.2011.576725

Reuters. (2020, April 9). Saudi, Russia outline record oil cut under U.S. pressure as demand crashes. New York Times. Retrieved from https://www.nytimes.com/reuters/2020/04/09/business/09reuters-global-oil-opec.html

Robin, C. (2004). Fear: The history of a political idea. Oxford University Press.

Sarasin, P. (2020, March 21). Understanding the coronavirus pandemic with foucault?. https://doi.org/10.13095/uzh.fsw.fb.254

Sideri, S. (2000). Globalization and regional integration. In S. Peige (Ed.), Regions and development: politics, security and economics. London, Franc Cass.

Stiglitz, J. (2020, April 6). Internationalizing the crisis. Project-Syndicate. Retrieved from https://www.project-syndicate.org/commentary/COVID-19-impact-on-developing-emerging-economies-by-jose ph-e-stiglitz-2020-04

Tang, S. (2008). Fear in international politics: Two positions. International Studies Review, 10(3), 451-471.

World Health Organization WHO. (2020, April 14). Rolling updates on the coronavirus disease COVID-19. Retrieved from https://www.who.int/emergencies/diseases/novel-coronavirus-2019/events-as-they-happen

\section{Notes}

Note 1. Neo-realist theories, based on power politics, would hold that even if a state were to derive an absolute gain from cooperation it will refrain from entering into a cooperative relationship if it expects that its partner will benefit relatively more from the relationship and will end up comparatively stronger. Neorealists argue that since the developing countries lack the domestic legitimacy to defend their economic resources their elite tend to form alliances with the more powerful countries. Levy and Barnett have argued that "there is an incentive for political leaders to ally with an economically more powerful state that might provide scarce resources, which, in turn, might help resolve internal economic and political problems" (1992).

Note 2. Neo-liberals in contrast to neo-realist view, place much more stress on cooperation among states. They tend to see cooperation among states as the rule, rather than the exception, especially in those areas where policy coordination, is necessary to realize the procurement of public goods, such as stable monetary relations, free trade or sustainable ecological development. Neo-liberals believe that, by encouraging domestic economies to compete in the world market, regional integration will lead to multilateral cooperation on a global scale and thus reduce conflict.

\section{Copyrights}

Copyright for this article is retained by the author(s), with first publication rights granted to the journal.

This is an open-access article distributed under the terms and conditions of the Creative Commons Attribution license (http://creativecommons.org/licenses/by/4.0/). 